\title{
A DEBRECENI TOP 9 FITNESZ SZOLGÁLTATÓ VÁLLALKOZÁS GAZDASÁGI ELEMZÉSE
}

\section{ECONOMIC ANALYSIS OF THE TOP 9 FITNESS SERVICE COMPANY IN DEBRECEN}

\author{
Szabóné Szőke Réka ${ }^{1}$ Pfau Christa², Bartha Éva³, Müller Anetta4, Bácsné Bába Éva ${ }^{5}$ \\ 1, Számviteli és Pénzügyi Intézet, Gazdaságtudományi Kar, Debreceni Egyetem, Magyarország \\ 3,4,5 Sportgazdasági és -menedzsment Intézet, Gazdaságtudományi Kar, Debreceni Egyetem, \\ Magyarország
}

\author{
Kulcsszavak: \\ fitnesz szektor \\ profitorientált fitness szolgáltatók \\ gazdasági elemzés \\ beszámoló \\ Keywords: \\ fitness sector \\ profit-oriented fitness club \\ economic analysis \\ Annual Report
}

\begin{abstract}
Összefoglalás
Debrecenben 11 olyan nagyobb méretü fitnesz terem van, ahol szolgáltatásként megjelenik a csoportos edzés is. Ezeket a fitnesztermeket mind ezen szolgáltatás, mind területük, mind gépparkjuk alapján a város vezető fitnesz szolgáltatóiként azonosíthatjuk be. Ezen fitnesz szolgáltatók gazdasági elemzését végeztük el éves beszámoló adataik alapján. Végül 9 fitnesz szolgáltató mérleg és eredménykimutatásának adatait sikerült összegyújteni, melyek segítségével a vizsgált szervezetek vagyoni, pénzügyi, jövedelmi helyzetét elemeztük. Megállapítható, hogy a vizsgált fitnesztermek vagyonszerkezete profiljukhoz illeszkedő, azaz dominálnak az ingatlanba, a gépparkba történö befektetések, melyek gyakorta külsö forrásokra támaszkodva valósíthatóak meg. Ezzel összefüggésben felmerül az eladósódottság veszélye, ami arra hívja fel a debreceni nagy fitnesztermek figyelmét, hogy a jövőben mind jövedelmezőségük, mind pénzügyi stabilitásuk fejlesztése érdekében szükséges lépéseket tenniük.
\end{abstract}

\section{Abstract}

There are 11 larger fitness clubs in Debrecen, where group training also appears as a service. These fitness centers can be identified as the leading fitness providers in the city based on this services, their area size and their machine park. We performed an economic analysis of these fitness providers based on their annual report data. Finally, the data of the balance sheets and income statements of 9 fitness service providers were collected, with the help of these statements we analyzed the wealth, financial and income situation of the examined organizations. It can be stated that the balance sheet of the examined fitness clubs is in line with their profile, ie investments in real estate and machinery dominate, which can often be realized by relying on external sources. In this context, there is a risk of indebtedness, which calls the attention of these large fitness centers in Debrecen to take the necessary steps to improve both their profitability and financial stability in the future. 


\section{Bevezetés}

A fitnesz ágazatban ahhoz, hogy egy vállalkozás versenyképes legyen a szolgáltatási környezet elemzése szükséges. Így a fitnesziparral kapcsolatos korábbi kutatások a szolgáltatás minőségére fókuszáltak, különös tekintettel a berendezésekre, a program kínálatra, a létesítményre és kiegészítő szolgáltatásokra [9] [5] [10] [21].

A szolgáltatás minőségének elemzése mellett a vevői elégedettség volt a másik leginkább vizsgált terület [16] [22] [1] [13]. Ez a két terület ugyanis az, amely leginkább meghatározza egy fitnesz szolgáltató vállalkozás profit céljainak megvalósulását.

A huszadik század utolsó évtizedei óta a fitneszipar világszerte jelentős növekedést mutat [12] [17] [20], megfigyelhető a profitorientált sport szolgáltatók számának növekedése [15]. Ez a világ szintű tendencia különösen erősen jelentkezik Európában és Észak-Amerikában. Egy kutatás a fitnesz- és egészségklubok számának 111 százalékos növekedését tárta fel 1998 és 2008 között az USA-ban. Lucassen és Van Schendel (2008) Hollandia, az Egyesült Királyság és Belgium esetében állapít meg hasonló arányú fejlődést [11].

A profitorientált szektorokra jellemző verseny helyzet által kikényszerített innováció [8] a sportipar területén is jelentkezik. Mint a legtöbb erősen versenyző piacon, a fitnesz ágazatban múködő szervezetekre is jellemző az újítás, piaci pozíciójuk fenntartása érdekében [6]. Ez új edzésprogramok és fitneszeszközök folyamatos kifejlesztésében, illetve alacsony költségvetésü fitnesz klubok, illetve fitneszszolgáltatási láncok megjelenésében jelentkezett ebben a szektorban [18] [4].

A fitnesz ipar gazdasági súlyának növekedésére utal Európában az egészség és fitnesz piac árbevételének 1,9\%-os növekedése 2017-ben (26,6 millió euró), és 2,25\%-os növekedése 2018-ban (27,2 millió euró). A piaci növekedés hajtóereje 2017-ben a fitnesz klubok számának 3,2\%-os emelkedése volt, amely együtt járt klubonként átlagosan 0,7\%-os, összességében pedig 4,0\%-os klubtagság növekedéssel. A fitnesz klubtagok száma 2018-ban elérte a 60 milliós összlétszámot (Deloitt 2018). A Deloitt 2019-es felmérése a fitnesz szektor további piaci növekedését mutatja, a klubok száma 4,6\% -kal, az európai klubtagság pedig közel 62,2 millióra emelkedett (Deloitt 2019). A fitnesz fogyasztók költéshajlandósága is nőtt, míg 2017ben átlagosan 38,6 euró/fó volt a havi költési hajlandóság fitnesz szolgáltatásokra, addig 2018ban ez 39,3 euró/fó/hóra emelkedett [14].

\section{Anyag és módszer}

Debrecenben 11 olyan nagyobb méretü fitnesz terem van, ahol szolgáltatásként megjelenik a csoportos edzés is. Ezeket a fitnesztermeket mind ezen szolgáltatás, mind területük, mind gépparkjuk alapján a város vezető fitnesz szolgáltatóiként azonosíthatjuk be. Ezen fitnesz szolgáltatók gazdasági elemzését kívántuk elvégezni éves beszámoló adataik alapján. „A gazdasági elemzés a gazdasági vezetés nélkülözhetetlen eszköze, lényegében olyan módszer, mellyel a gazdasági vezetés részére biztosítható a nélkülözhetetlen tájékozottság, a vállalkozási tevékenység megismerhető, bírálható és fejleszthető” [2]. Kutatási eredményeink azonban nemcsak a cégvezetők számára szolgálhatnak hasznos információval, de a fitnesz ágazat debreceni helyzetének felmérését is jelenti.

A kiválasztott cégek gazdasági elemzéséhez végzett a számításokhoz a mérleg és eredménykimutatás információtartalmát használtuk fel 2015-2018 közötti időszakban. A vállalkozásokat néhány kiválasztott vagyoni, pénzügyi és jövedelmezőségi helyzetet jellemző mutató alapján elemeztük. A cégek anonimitását megőrizendő, számokkal jelöltük a vállalkozásokat vizsgálatunkban. Sajnálatos módon két fitneszterem esetében nem sikerült a beszámoló adatok összegyüjtése, így 9 szervezet elemzését tudtuk elvégezni. A kiválasztott cégek között ebben az időszakban van egy újonnan alakuló vállalkozás, a 7. cég, mellyel kapcsolatban emiatt 2015-ben és 2016-ban nem lehetett számításokat végezni. Továbbá a 8. cég 2018-ra átalakult, megszűnt így ott sem lesznek releváns számítások az adott évben. 


\section{Eredmények}

\subsection{A vizsgált fitnesz vállalkozások jövedelmezôségi helyzetének elemzése 2015-2018 között}

A kiválasztott sportszolgáltatást végző cégek jövedelmezőségi helyzetének vizsgálata során a ROA (Return on Assets), a ROE (Return on Equity) és a ROS (Return on Sales) mutatókat számítottuk, melyek értékei az 1.táblázatban láthatóak. A mutatók választ adnak arra, hogy mennyire jövedelmezőek a vállalkozások. A kiszámított értékek esetében azt tekintjük kedvezőnek, ha folyamatos növekedést mutatnak.

A ROA mutató az eszközök jövedelemtermelő képességét fejezi ki azaz, hogy mekkora hozamot lehet elérni az eszközök müködtetése által. Kiszámítása során az adózott eredményt osztjuk az összes eszköz értékével [3]. A kilenc kiválasztott cég közül egyik sem mutat igazán növekedést, szinte majdnem mindegyik vállalkozásnál az a tendencia, hogy 2015-ről 2016-ra növekszik, majd 2017-ben a mutató értéke visszaesik, illetve néhány cég kivételével 2018-ra tovább csökkennek az értékek.

A ROE mutató a vállalkozás tulajdonosai számára a legfontosabb jövedelmezőségi mutató, mivel kiszámításával arra kapunk választ, hogy a tulajdonosok által birtokolt saját tőke mekkora hozamot tud biztosítani. A ROE mutatót az adózott eredmény és a saját tőke hányadosaként kapjuk meg [3]. Vizsgálni lehetne még a tókeáttételt is, hiszen a ROE mutató esetében érvényesülhet a hatása. A saját tőke hozama akkor növelhető, ha az eszközök hozama nagyobb, mint az idegen tőke költsége. Arra is figyelemmel kell lenni a ROE értékek esetében, hogy a hitelek aránytalan mennyisége révén csökken a saját tôke értéke, kevesebb lesz az adózott eredmény és magas a ROE értéke. A ROE mutatók jelen vállalkozások esetében jelentős csökkenést mutatnak. A negatív eredmények a negatív eredménytartaléknak vagy adózott eredménynek köszönhetőek. Az eredménytartalék az előző évek nyereségét vagy veszteségét tartalmazzák, míg az adózott eredmény a tárgyév eredményét mutatja ki [23].

A ROS mutató az árbevétel jövedelemtermelő képességét jelenti, mely mutató esetében szinte majdnem mindegyik vállalkozásnál a ROA tendenciáját követve 2015-ről 2016-ra növekszik, majd 2017-ben az értéke visszaesik. 2018-ra két cég kivételével a ROS értékek növekednek. A ROS mutató kiszámítása úgy zajlik, hogy az adózott eredményt osztjuk az értékesítés nettó árbevételével [3].

A vállalkozások eredménykimutatását vizsgálva mindegyik cégre elmondható, hogy az árbevételhez képest magas az anyagjellegü ráfordítások értéke, ezek a legnagyobb értékkel bíró ráfordítások. Az adózott eredmények értéke igazán jelentős növekedést csak az 5. és a 9. cég esetében mutat. A legkedvezőbben a 9. cég jövedelmezősége alakult, ahol folyamatosan növekedett az árbevétel, a saját tőke és a vagyon összege is.

\section{Táblázat: A vizsgált fitnesz vállalkozások jövedelmezőségi mutatóinak értéke 2015-} 2018 között

\begin{tabular}{|r|r|l|l|l|}
\hline \multicolumn{2}{|l}{$\begin{array}{l}\text { Jövedelmezóségi } \\
\text { mutatók }\end{array}$} & ROA & ROE & ROS \\
\hline & $\mathbf{2 0 1 5}$ & $2,74 \%$ & $-10,16 \%$ & $3,60 \%$ \\
\cline { 2 - 5 } & $\mathbf{2 0 1 6}$ & $7,48 \%$ & $-43,43 \%$ & $7,92 \%$ \\
\cline { 2 - 5 } & $\mathbf{2 0 1 7}$ & $2,11 \%$ & $-44,04 \%$ & $2,13 \%$ \\
\hline & $\mathbf{2 0 1 8}$ & $0,89 \%$ & $-33,26 \%$ & $1,33 \%$ \\
\hline & $\mathbf{2 0 1 5}$ & $13,73 \%$ & $53,31 \%$ & $13,89 \%$ \\
\hline \multirow{3}{*}{$\mathbf{2 .}$} & $\mathbf{2 0 1 6}$ & $31,78 \%$ & $51,27 \%$ & $25,70 \%$ \\
\hline & $\mathbf{2 0 1 7}$ & $18,90 \%$ & $30,05 \%$ & $17,71 \%$ \\
\hline \multirow{3}{*}{3.} & $\mathbf{2 0 1 8}$ & $1,04 \%$ & $2,01 \%$ & $1,43 \%$ \\
\cline { 2 - 5 } & $\mathbf{2 0 1 5}$ & $2,96 \%$ & $5,40 \%$ & $1,90 \%$ \\
\cline { 2 - 5 } & $\mathbf{2 0 1 6}$ & $2,07 \%$ & $2,66 \%$ & $0,91 \%$ \\
\hline & $\mathbf{2 0 1 7}$ & $0,60 \%$ & $2,40 \%$ & $0,86 \%$ \\
\hline
\end{tabular}




\begin{tabular}{|c|c|c|c|c|}
\hline & 2018 & $0,48 \%$ & $2,25 \%$ & $0,88 \%$ \\
\hline \multirow[b]{4}{*}{4.} & 2015 & $-21,05 \%$ & $83,16 \%$ & $-21,37 \%$ \\
\hline & 2016 & $1,13 \%$ & $22,93 \%$ & $2,22 \%$ \\
\hline & $\mathbf{2 0 1 7}$ & $0,56 \%$ & $22,94 \%$ & $0,63 \%$ \\
\hline & 2018 & $0,78 \%$ & $23,05 \%$ & $1,54 \%$ \\
\hline \multirow[b]{4}{*}{5.} & 2015 & $2,65 \%$ & $50,34 \%$ & $6,84 \%$ \\
\hline & 2016 & $3,28 \%$ & $46,67 \%$ & $9,68 \%$ \\
\hline & 2017 & $0,51 \%$ & $14,32 \%$ & $2,04 \%$ \\
\hline & 2018 & $3,93 \%$ & $51,99 \%$ & $8,46 \%$ \\
\hline \multirow[b]{4}{*}{6.} & 2015 & $-24,26 \%$ & $47,00 \%$ & $-27,24 \%$ \\
\hline & 2016 & $3,22 \%$ & $-6,28 \%$ & $2,18 \%$ \\
\hline & 2017 & $309,25 \%$ & $1069,83 \%$ & $-15,60 \%$ \\
\hline & 2018 & $45,00 \%$ & $174,92 \%$ & $3,20 \%$ \\
\hline \multirow[b]{4}{*}{7.} & 2015 & - & - & - \\
\hline & 2016 & - & - & - \\
\hline & 2017 & $-1,11 \%$ & $-5,93 \%$ & - \\
\hline & 2018 & $-6,02 \%$ & $-123,20 \%$ & $-18,81 \%$ \\
\hline \multirow[b]{4}{*}{8.} & 2015 & $6,14 \%$ & $15,77 \%$ & $18,10 \%$ \\
\hline & 2016 & $-6,29 \%$ & $-13,24 \%$ & $-25,64 \%$ \\
\hline & 2017 & $220,80 \%$ & $241,36 \%$ & $384,87 \%$ \\
\hline & 2018 & - & - & - \\
\hline \multirow[b]{4}{*}{9.} & 2015 & $-24,61 \%$ & $106,52 \%$ & $-35,23 \%$ \\
\hline & 2016 & $2,20 \%$ & $10,20 \%$ & $1,73 \%$ \\
\hline & 2017 & $0,58 \%$ & $3,39 \%$ & $0,90 \%$ \\
\hline & 2018 & $28,72 \%$ & $69,11 \%$ & $24,68 \%$ \\
\hline
\end{tabular}

Forrás: Saját számítások a vállalkozások beszámolói alapján

\subsection{A vizsgált fitnesz vállalkozások pénzügyi helyzetének elemzése 2015-2018 között}

A likviditási mutatók esetében számíthatunk általános, gyors és azonnali likviditási mutatót, melyek megmutatják, hogy mennyire fizetőképesek a vállalkozások rövidtávon (1. ábra). Az általános likviditási mutató esetében a forgóeszközöket osztjuk a rövid lejáratú kötelezettségekkel. Elvárt értéke 1,3-1,7 között mozog, de természetesen iparáganként ez eltérő lehet. A gyors likviditási ráta kiszámítása során a forgóeszközök értékéből levonásra kerül a legkevésbé likvid eszköz, azaz a készletek. Ennek a mutatónak az elvárt értéke 0,8-1 között mozog. Míg az azonnali likviditási ráta elvárt értéke o,25-0,3. Ennél a mutatónál csak a leglikvidebb eszközöket, az értékpapírokat és a pénzeszközöket hasonlítjuk a rövid lejáratú kötelezettségek értékéhez. Amennyiben a mutatók nagyon alacsonyak, nem tekintjük likvidnek a vállalkozásokat és fennállhat a fizetésképtelenség veszélye, de a túl magas mutató sem mondható kedvezőnek, hiszen ebben az esetben a vállalkozás túl sok forgóeszközt halmoz fel és nem fektet be, nem fejleszt [3].

Az általános likviditási ráta esetében csak a 4. és a 6. cég tudta az elvárt értékeket hozni, de csak néhány évben. A mutatók inkább alacsonyak és nem érik el az elvárt 1,3-as értéket mivel nagyon alacsonyak a forgóeszköz értékek a rövid lejáratú kötelezettségekhez képest. Néhány esetben viszont rendkívül magas értéket is kaptunk, amikor nagyon alacsony rövid lejáratú kötelezettségekhez egy magasabb forgóeszköz érték társult. A gyors likviditási ráta értékei csak a 6. és a 9. cég esetében, és akkor is csak a 3. évben érték el a o,8-1 közötti értéket. Általában inkább o,8 alatti értékeket kaptunk, mivel a készletek értéke jellemzően nem magas. Azonnali likviditási ráta esetében viszont egyik évben sem esik a mutató értéke a megadott 
tartomány közé, mivel értékpapírjuk egyáltalán nincs a cégeknek és a pénzeszközeik értéke is nagyon alacsony.

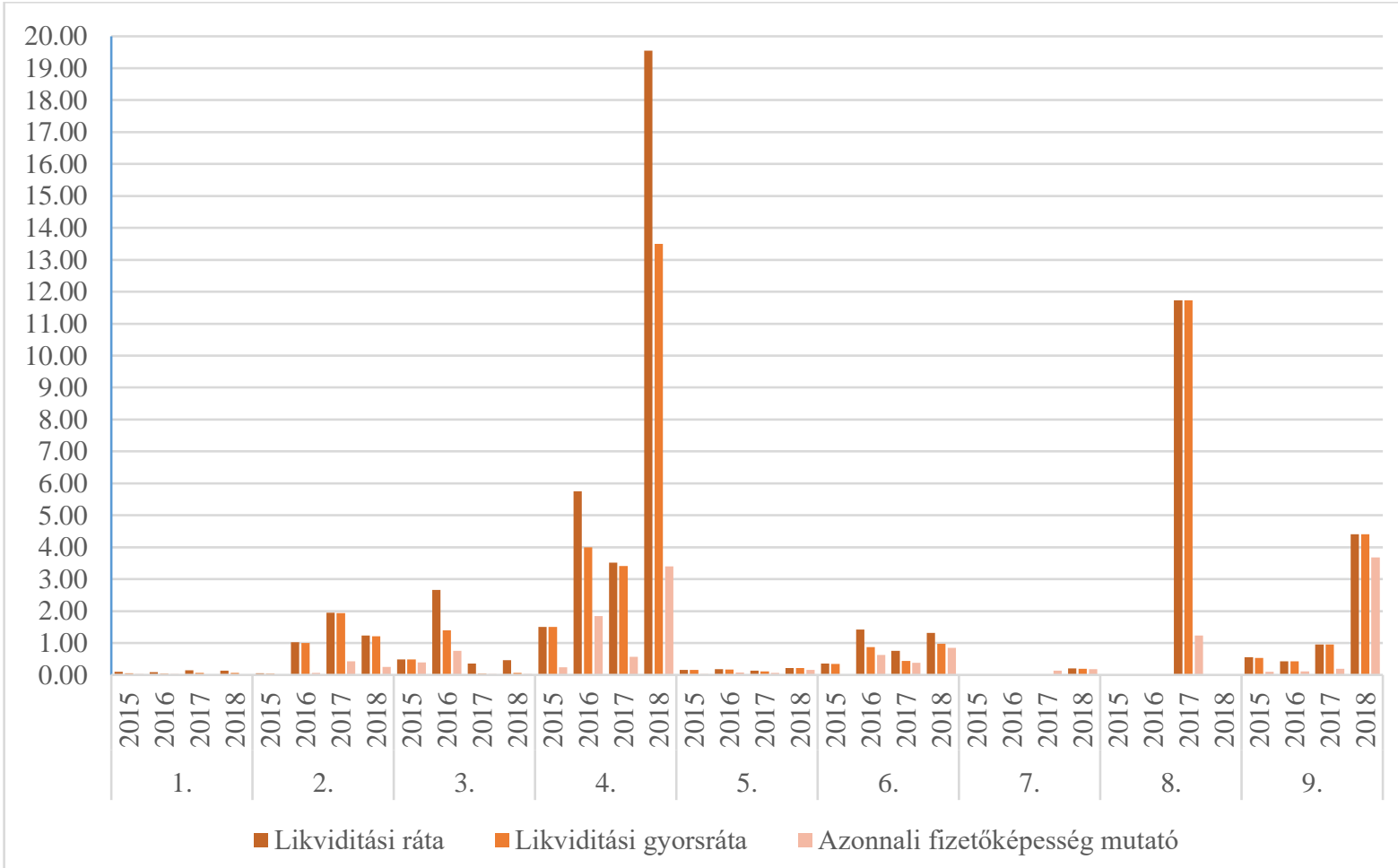

1. ábra: A kiválasztott vállalkozások likviditási mutatóinak értéke 2015-2018 között Forrás: Saját számítások a vállalkozások beszámolói alapján, 2019

A rövid távú pénzügyi helyzetet követően a hosszú távú pénzügyi helyzetet vizsgáltuk, az általunk számított mutatók értékeit a 2. táblázat tartalmazza.

2. Táblázat: A kiválasztott vállalkozások hosszú távú pénzügyi helyzet mutatóinak értéke 2015-2018 között

\begin{tabular}{|c|c|c|c|c|c|}
\hline \multicolumn{2}{|c|}{$\begin{array}{l}\text { Hosszú } \\
\text { távú } \\
\text { pénzügyi } \\
\text { helyzet } \\
\text { mutatói }\end{array}$} & \multirow{2}{*}{$\begin{array}{l}\text { Adósság/ } \\
\text { Saját tóke } \\
\text { arány }\end{array}$} & \multirow[t]{2}{*}{$\begin{array}{l}\text { Hosszú lejáratú } \\
\text { eladósodottság } \\
\text { (Adósságállomány } \\
\text { aránya) } \\
86,87 \\
\end{array}$} & \multirow{2}{*}{\begin{tabular}{|l}
$\begin{array}{l}\text { Adósságállomány } \\
\text { fedezettsége }\end{array}$ \\
$-0,99$
\end{tabular}} & \multirow{2}{*}{\begin{tabular}{|l}
$\begin{array}{r}\text { Saját tóke } \\
\text { multiplikátor }\end{array}$ \\
$-3,71$ \\
\end{tabular}} \\
\hline \multirow[b]{4}{*}{1.} & 2015 & & & & \\
\hline & 2016 & $-6,80$ & 5,71 & $-0,82$ & $-5,80$ \\
\hline & 2017 & $-21,86$ & 1,40 & $-0,29$ & $-20,86$ \\
\hline & 2018 & 1,03 & 0,00 & - & $-37,21$ \\
\hline \multirow[b]{4}{*}{2.} & 2015 & 2,88 & 0,41 & 1,43 & 3,88 \\
\hline & 2016 & 0,61 & 0,21 & 3,81 & 1,61 \\
\hline & 2017 & 0,59 & 0,20 & 3,95 & 1,59 \\
\hline & 2018 & 0,48 & 0,34 & 1,97 & 1,93 \\
\hline \multirow{6}{*}{3.} & 2015 & 0,82 & 0,06 & 14,92 & 1,82 \\
\hline & 2016 & 0,29 & 0,00 & - & 1,29 \\
\hline & 2017 & 3,00 & 0,00 & - & 4,00 \\
\hline & 2018 & 0,79 & 0,00 & - & 4,68 \\
\hline & 2015 & $-4,95$ & 1,27 & $-0,22$ & $-3,95$ \\
\hline & 2016 & 19,34 & 0,95 & 0,05 & 20,34 \\
\hline
\end{tabular}




\begin{tabular}{|l|l|l|l|l|l|} 
& $\mathbf{2 0 1 7}$ & 40,05 & 0,94 & 0,07 & 41,05 \\
\hline $\mathbf{2 0 1 8}$ & 0,97 & 0,97 & 0,04 & 29,69 \\
\hline $\mathbf{2 0 1 5}$ & 18,03 & 0,93 & 0,08 & 19,03 \\
\hline $\mathbf{2 0 1 6}$ & 13,24 & 0,90 & 0,11 & 14,24 \\
\hline $\mathbf{2 0 1 7}$ & 26,99 & 0,94 & 0,06 & 27,99 \\
\hline $\mathbf{2 0 1 8}$ & 0,92 & 0,87 & 0,15 & 13,21 \\
\hline $\mathbf{2 0 1 5}$ & $-2,94$ & $-22,75$ & $-1,04$ & $-1,94$ \\
\hline $\mathbf{2 0 1 6}$ & $-2,95$ & 1,55 & $-0,36$ & $-1,95$ \\
\hline $\mathbf{2 0 1 7}$ & $-4,46$ & $-0,43$ & $-3,31$ & $-3,46$ \\
\hline $\mathbf{2 0 1 8}$ & 0,74 & 0,00 & - & 3,89 \\
\hline $\mathbf{2 0 1 5}$ & - & - & - & - \\
\hline $\mathbf{2 0 1 6}$ & 0,00 & 0,00 & - & 1,00 \\
\hline $\mathbf{2 0 1 7}$ & 4,37 & 0,00 & - & 5,37 \\
\hline $\mathbf{2 0 1 8}$ & 0,95 & 0,00 & - & 20,47 \\
\hline $\mathbf{2 0 1 5}$ & 1,57 & 0,25 & 3,06 & 2,57 \\
\hline $\mathbf{2 0 1 6}$ & 1,11 & 0,12 & 7,43 & 2,11 \\
\hline $\mathbf{2 0 1 7}$ & 0,09 & 0,00 & - & 1,09 \\
\hline $\mathbf{2 0 1 8}$ & - & - & - & - \\
\hline $\mathbf{2 0 1 5}$ & $-5,33$ & 1,65 & $-0,40$ & $-4,33$ \\
\hline $\mathbf{2 0 1 6}$ & 3,63 & 0,00 & - & 4,63 \\
\hline $\mathbf{2 0 1 7}$ & 4,80 & 0,70 & 0,42 & 5,80 \\
\hline $\mathbf{2 0 1 8}$ & 0,58 & 0,47 & 1,14 & 2,41 \\
\hline
\end{tabular}

Forrás: Saját számítások a vállalkozások beszámolói alapján

A 2. táblázat az Adósság/Saját tőke aránya mutatót, a Hosszú lejáratú eladósodottság arányát, az Adósságállomány fedezettségét és a Saját tőke multiplikátor mutatót tartalmazza. Az első mutató, az Adósság/Saját tőke aránya mutató, mely megmutatja, hogy az idegen tőke hányszorosa a saját tőke értékének. Azok a vállalkozások, ahol a pénzbeáramlás kiegyensúlyozott elbírnak egy magasabb értéket is, míg ellenkező esetben a minél alacsonyabb érték a kedvezőbb [19]. A negatív értékek a negatív eredménytartaléknak vagy adózott eredménynek köszönhetőek. Általában minden cégnél meghaladja az 1-es értéket a mutató, azaz nagyobb az idegen tőke értéke. A Hosszú lejáratú eladósodottság mutató kiszámítása úgy történik, hogy a hosszú lejáratú kötelezettségek értékét osztjuk a saját tőke és a hosszú lejáratú kötelezettségek összegével, ami megmutatja, hogy milyen arányban van hosszú távon eladósodva a vállalkozás. Az Adósságállomány fedezettsége mutató értékét a saját tőke és a hosszú lejáratú kötelezettségek hányadosaként kapjuk meg, mely mutató kifejezi, hogy hányszorosan fedezi a saját tőke a hosszú lejáratú kötelezettségeket [19]. Néhány cégnél (2., 3., 8. és 9.) és csak néhány évben fordul ez elő, többségében nem képesek fedezni a saját tôkével a hosszú lejáratú kötelezettségek értékét. Végül a saját tőke multiplikátor mutató megmutatja, hogy a tulajdonosok által rendelkezésre bocsájtott tőke milyen eszközállományt volt képes létrehozni, hányszorosan sikerült megtöbbszörözni a tulajdonosoknak a saját vagyonukat [19]. Jellemzően minimálisan, de mégis csak tapasztalható a vagyon növekedése, 2015-ről 2016-ra figyelhető meg a legtöbb esetben, mely 2017-re általában lecsökken és 2018-ra a cégek fele esetében csökken, másik felében pedig növekszik.

\subsection{A vizsgált fitnesz vállallkozások vagyoni helyzetének elemzése 2015-2018 között}

A vállalkozások vagyoni helyzetének elemzéséhez a beszámoló részeként elkészítendő mérleg szolgáltat adatokat. A vagyoni helyzet elemzésekor számíthatunk horizontális és vertikális mutatókat. Az utóbbi csak az eszköz, vagy csak a forrás oldalról vesz adatokat és 
megoszlási viszonyszámok segítségével eszközszerkezeti és tőkeszerkezeti jellemzőket kapunk. A horizontális mutatók az eszköz és a forrás oldal adatait viszonyítják egymáshoz [7]. Cikkünkben elsőnek az eszköz oldal megoszlását mutatjuk be a kiválasztott cégeknél 20152018 között. Ezeket az értékeket a 2. ábra mutatja be. Az ábrán azt láthatjuk, hogy vállalkozásoknál jellemzően a befektetett eszközöknek magasabb az aránya az összes eszközön belül. A befektetett eszközökön belül a vállalkozások nem rendelkeznek befektetett pénzügyi eszközökkel egyik évben sem, továbbá nagyon kevés az a cég, amelynek van immateriális jószága, és amennyiben van is, akkor annak minimális az értéke. A befektetett eszközök szerkezete illeszkedik a vállalkozási profilhoz, azaz ingatlanok, illetve értékes fitneszgépek képezik a fitneszszolgáltatók vagyonának több éven keresztül hasznosuló részét. A 6. cég kivételével a befektetett eszközök értéke 2015-ről 2016-ra csökkent, ezt követően nagyon változatosan alakult ezeknek az értéke, van olyan cég, amelynél növekedés, van ahol csökkenés volt tapasztalható. Ennek hátterében eszköz beszerzés, illetve az értékcsökkenési leírás hatása érzékelhető. A forgóeszközök megoszlása az összes eszközön belül szinte 100\%-ra egészíti ki a befektetett eszközök arányát, hiszen a legtöbb cég minimális aktív időbeli elhatárolással rendelkezik, mint ahogyan az az ábrán is látható. A forgóeszközökön belül a készletek és a követelések rendelkeznek a legnagyobb aránnyal, értékpapírja egyik cégnek sincs, pénzeszköze minimális

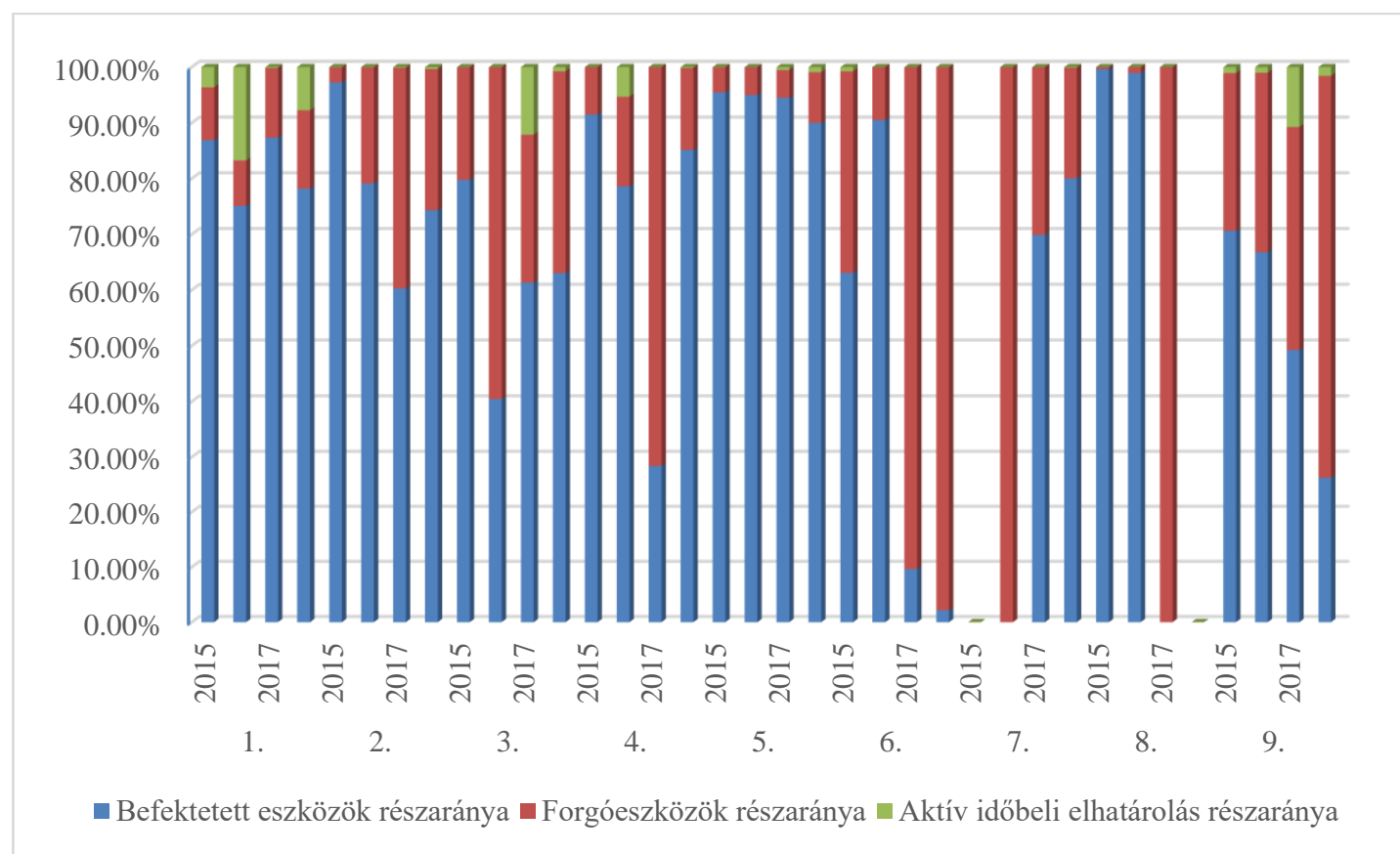

2. ábra: A vizsgált fitnesz vállalkozások eszközeinek megoszlása 2015-2018 között Forrás: Saját számítások a vállalkozások beszámolói alapján

Az eszközoldal megoszlásának vizsgálatát a forrás oldal követi, ahol saját tőke megoszlása sokszor negatív értékeket vesz fel a negatív eredménytartalék vagy adózott eredmény miatt. Ilyen cég például az 1., 4., 6., és 9. cég. Az is megfigyelhető, hogy egyik cég sem rendelkezik céltartalékkal, valamint hasonlóan az eszköz oldalhoz, kevés az elhatárolások értéke. A legtöbb cég nem tőkeerős vállalkozás, hiszen a saját tőke aránya nem éri el az elvárt 30\%-ot. Ez alól csak a 3. és a 8. cég kivétel, ahol a mutatók értéke eléri vagy meg is haladja azt. A kötelezettségek magas arányát tovább lehet vizsgálni, és belső megoszlást számítani. Az viszont megfigyelhető, hogy a kritikus 70\%-ot a legtöbb vállalkozásnál meghaladják a mutatók értékei és ezáltal fennállhat az eladósodottság veszélye. 


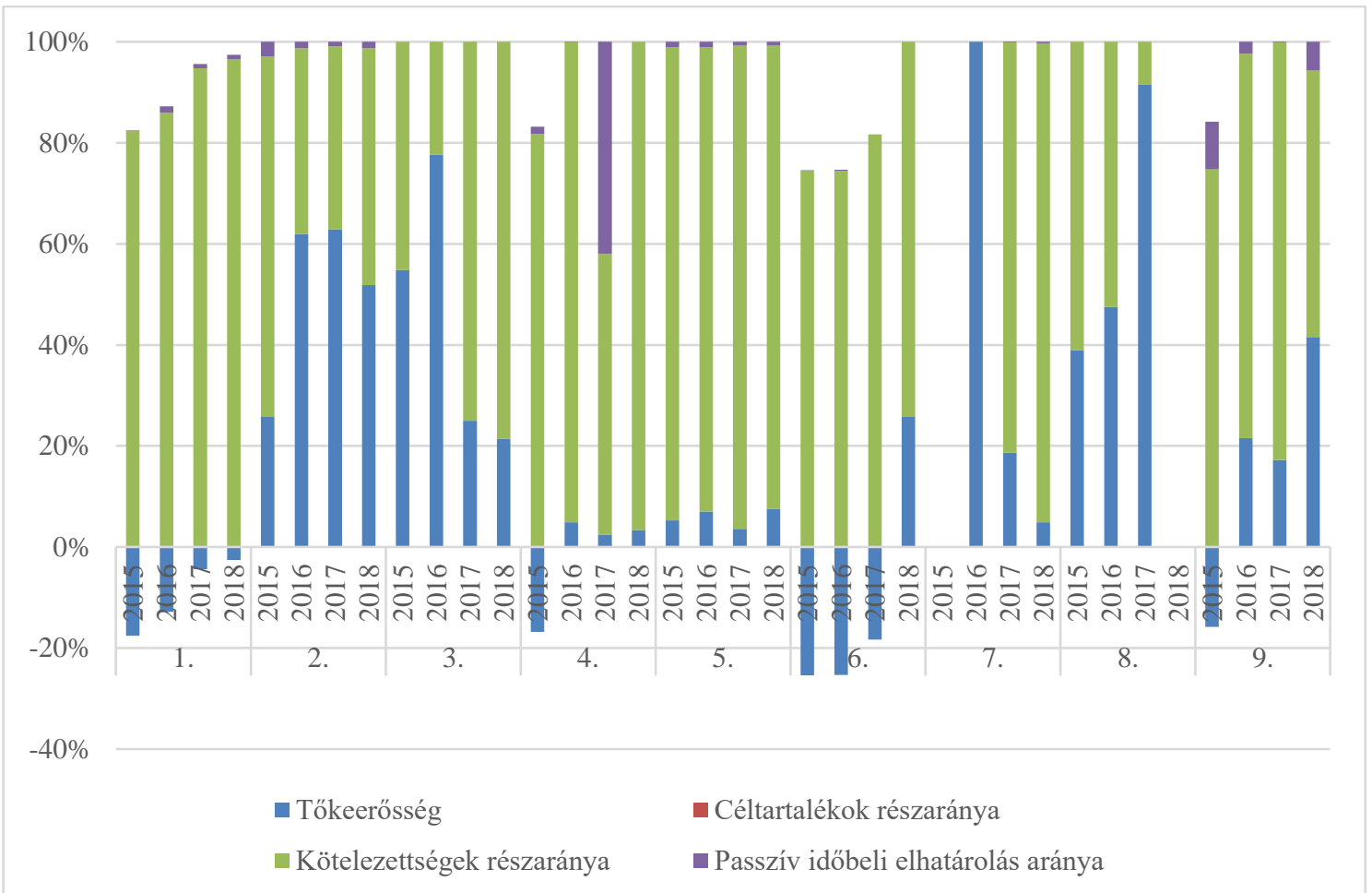

3. ábra: A vizsgált fitnesz vállalkozások forrásainak megoszlása 2015-2018 között Forrás: Saját számítások a vállalkozások beszámolói alapján, 2019

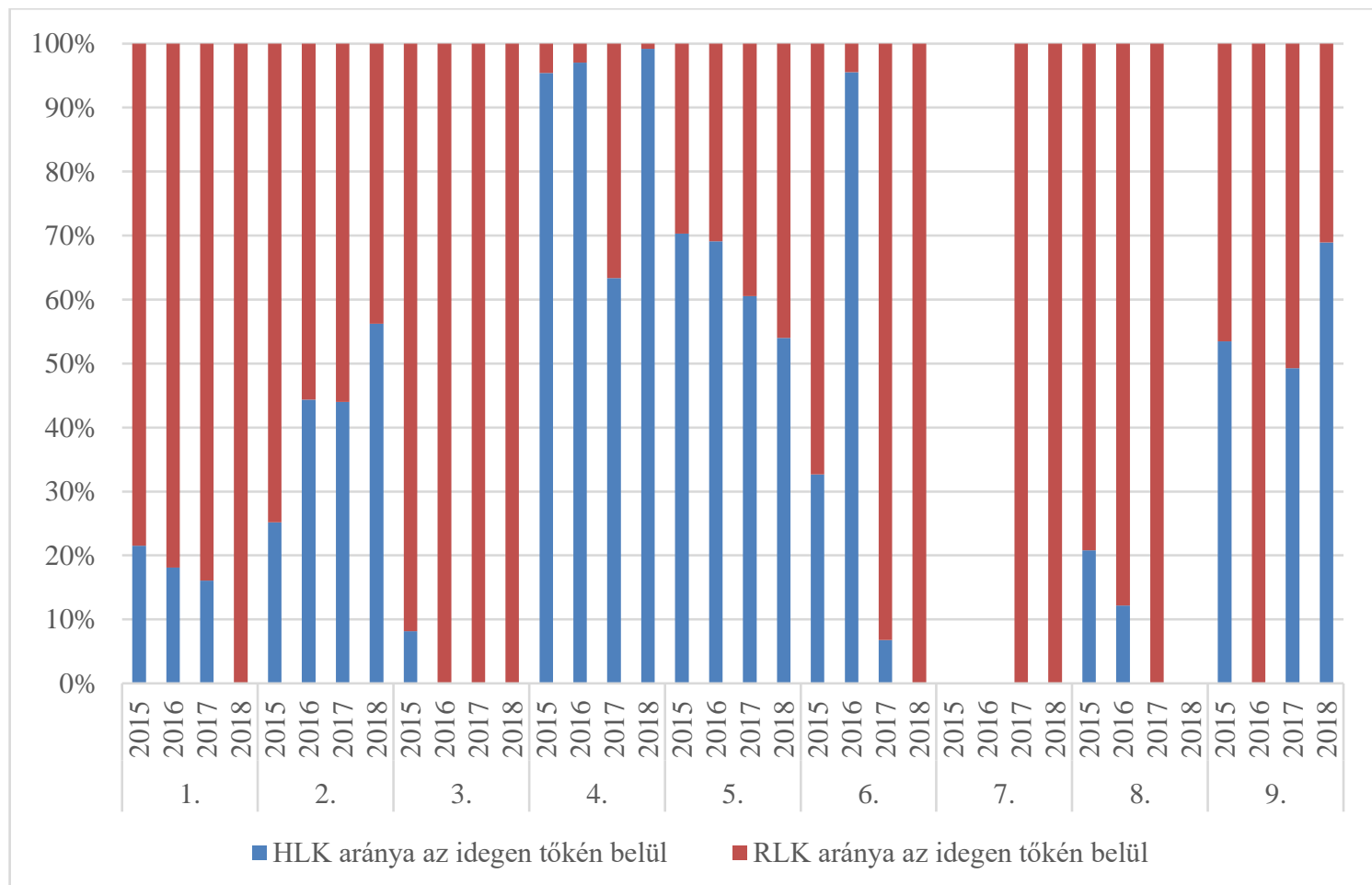

4. ábra: A vizsgált fitnesz vállalkozások kötelezettségeinek megoszlása 2015-2018 között Forrás: Saját számítások a vállalkozások beszámolói alapján, 2019

A vertikális mutatók számítása alkalmas arra is, hogy egy főcsoporton belül nézzük meg a mérlegtételek alakulását. A vizsgált négy év alatt hátrasorolt kötelezettségei nem voltak a cégeknek. A 3. és a 7. cégek egyáltalán nem, vagy csak alacsony hosszú lejáratú kötelezettséggel rendelkeznek. A hosszú lejáratú kötelezettségek legnagyobb arányban a 4. és 5. cégnél fordulnak elő. 
Tovább folytatva a vagyoni helyzet vizsgálatát néhány horizontális mutatót is számítottunk, ezek a saját tőke változása és a befektetett eszközök fedezete mutatók. A kiszámított értékeket az 3. táblázat tartalmazza.

3. Táblázat: A vizsgált fitnesz vállalkozások vagyoni helyzet mutatóinak értéke 20152018 között

\begin{tabular}{|c|c|c|c|c|}
\hline $\begin{array}{l}\text { Vagyoni } \\
\text { mutatói }\end{array}$ & helyzet & $\begin{array}{l}\text { Saját } \quad \text { tóke } \\
\text { változása (\%) }\end{array}$ & $\begin{array}{l}\text { Befektetett } \\
\text { eszközök } \\
\text { fedezete (\%) }\end{array}$ & \begin{tabular}{|l} 
Befektetett \\
eszközök \\
fedezete II (\%)
\end{tabular} \\
\hline \multirow[b]{4}{*}{1.} & 2015 & $-10,16 \%$ & $-31,05 \%$ & $0,36 \%$ \\
\hline & 2016 & $-43,43 \%$ & $-22,94 \%$ & $4,87 \%$ \\
\hline & 2017 & $-44,04 \%$ & $-5,49 \%$ & $13,59 \%$ \\
\hline & 2018 & $-33,26 \%$ & $-3,44 \%$ & $-3,44 \%$ \\
\hline \multirow[b]{4}{*}{2.} & 2015 & $53,31 \%$ & $26,49 \%$ & $44,95 \%$ \\
\hline & 2016 & $51,27 \%$ & $78,36 \%$ & $98,94 \%$ \\
\hline & 2017 & $30,05 \%$ & $104,32 \%$ & $130,74 \%$ \\
\hline & 2018 & $2,01 \%$ & $69,73 \%$ & $105,20 \%$ \\
\hline \multirow[b]{4}{*}{3.} & 2015 & $5,40 \%$ & $68,74 \%$ & $73,35 \%$ \\
\hline & 2016 & $2,66 \%$ & $192,07 \%$ & $192,07 \%$ \\
\hline & 2017 & $2,40 \%$ & $40,72 \%$ & $40,72 \%$ \\
\hline & 2018 & $2,25 \%$ & $33,90 \%$ & $33,90 \%$ \\
\hline \multirow[b]{4}{*}{ 4. } & 2015 & $83,16 \%$ & $-27,66 \%$ & $100,69 \%$ \\
\hline & 2016 & $22,93 \%$ & $6,25 \%$ & $123,64 \%$ \\
\hline & 2017 & $22,94 \%$ & $8,58 \%$ & $132,73 \%$ \\
\hline & 2018 & $23,05 \%$ & $3,96 \%$ & $116,56 \%$ \\
\hline \multirow[b]{4}{*}{5.} & 2015 & $50,34 \%$ & $5,51 \%$ & $74,50 \%$ \\
\hline & 2016 & $46,67 \%$ & $7,40 \%$ & $74,30 \%$ \\
\hline & 2017 & $14,32 \%$ & $3,78 \%$ & $65,05 \%$ \\
\hline & 2018 & $51,99 \%$ & $8,41 \%$ & $63,48 \%$ \\
\hline \multirow[b]{4}{*}{6.} & 2015 & $47,00 \%$ & $-81,83 \%$ & $-3,45 \%$ \\
\hline & 2016 & $-6,28 \%$ & $-56,59 \%$ & $102,47 \%$ \\
\hline & 2017 & $1069,83 \%$ & $-299,58 \%$ & $-209,21 \%$ \\
\hline & 2018 & $174,92 \%$ & $1196,25 \%$ & $1196,25 \%$ \\
\hline \multirow[b]{4}{*}{7.} & 2015 & - & - & - \\
\hline & 2016 & $0,00 \%$ & - & - \\
\hline & 2017 & $-5,93 \%$ & $26,66 \%$ & $26,66 \%$ \\
\hline & 2018 & $-123,20 \%$ & $6,10 \%$ & $6,10 \%$ \\
\hline \multirow[b]{4}{*}{8.} & 2015 & $15,77 \%$ & $39,09 \%$ & $51,85 \%$ \\
\hline & 2016 & $-13,24 \%$ & $47,99 \%$ & $54,45 \%$ \\
\hline & 2017 & $241,36 \%$ & - & - \\
\hline & 2018 & - & - & - \\
\hline \multirow[b]{4}{*}{9.} & 2015 & $106,52 \%$ & $-32,71 \%$ & $50,02 \%$ \\
\hline & 2016 & $10,20 \%$ & $32,30 \%$ & $32,30 \%$ \\
\hline & 2017 & $3,39 \%$ & $35,01 \%$ & $117,68 \%$ \\
\hline & 2018 & $69,11 \%$ & $158,26 \%$ & $296,80 \%$ \\
\hline
\end{tabular}

Forrás: Saját számítások a vállalkozások beszámolói alapján 
Az 3. táblázat első mutatója a saját tőke változása mutató, mely a saját tőkét viszonyítja a jegyzett tôkéhez, megmutatja, hogy a saját tôke hányszorosára növekedett a jegyzett tôkéhez képest, míg a befektetett eszközök fedezet mutató az illeszkedés elvét hivatott szolgálni, azaz, hogy a tartós eszközöket tartós forrásból kell fedezni. Ebben az esetben az I. mutató esetében a saját tőkét és a befektetett eszközöket, míg a II. mutató esetében a saját tőke és hosszú lejáratú kötelezettségek együttes értékét hasonlítja a befektetett eszközökhöz. Ennek a két mutatónak az értékét akkor fogadjuk el, ha meghaladja a 100\%-ot [3]. Igazán egyik cégnél sem figyelhető meg egyenletes növekedés a saját tőke változása mutatónál, miközben jegyzett tőke emelésre, vagy leszállításra sem került sor a cégeknél. A befektetett eszközök fedezete mutatók az 1.,5., 7., és 8. cég esetében egyik évben sem érte el az elvárt 100\%-ot, a többi cég esetében is csak egy-egy évben haladta azt meg. A 4. cég az egyetlen, ahol minden évben meghaladta az elvárt értéket a Befektetett eszközök fedezete II. mutató, azaz amikor a saját tőke értékéhez már a hosszú lejáratú kötelezettségek értéke is hozzáadódik.

\section{Következtetések}

A debreceni piacvezető fitnesz szolgáltatást nyújtó vállalkozások gazdasági elemzése jövedelmi, pénzügyi, vagyoni helyzetükre terjedt ki.

A jövedelmi helyzet vizsgálata során kiderült sem az eszköz, sem a saját tőke, sem az árbevétel arányos jövedelmezősége nem megfelelő a vizsgált fitnesztermeknek. A vállalkozásoknak komolyabb figyelmet kell fordítaniuk a jövedelmezőségi helyzetük felülvizsgálatára.

A pénzügyi helyzet tekintetében megállapítható, hogy a vállalkozások rövid távú pénzügyi helyzete kedvezőtlenül alakult a vizsgált években, hiszen jellemzően nem elég likvidek a vállalkozások, míg a hosszú távú pénzügyi helyzet elemzésekor az eladósodottság veszélye is felmerül, hiszen jellemzően nem képesek fedezni az adósságaikat.

A fitnesz vállalkozások vagyoni helyzetéről az mondható el, hogy az eszköz szerkezeti mutatóknál a befektetett eszközök aránya mutató, a tôkeszerkezeti mutatóknál a kötelezettségek részaránya mutató értékei a legmagasabbak. Ezeknek a mutatóknak a fölénye viszonylag állandó a vizsgált években. A számított horizontális mutatók nem tükröznek stabilitást a kiválasztott cégek esetében, hiszen a saját tőkénél egyenletes növekedés nem volt tapasztalható és a befektetett eszközök fedezete mutató is csak nagyon ritkán, néhány cég esetében haladja meg a 100\%-ot.

Összességében megállapítható, hogy a vizsgált fitnesztermek vagyonszerkezete profiljukhoz illeszkedő, azaz dominálnak az ingatlanba, a gépparkba történő befektetések, melyek gyakorta külső forrásokra támaszkodva valósíthatóak meg. Ezzel összefüggésben felmerül az eladósódottság veszélye, ami arra hívja fel a debreceni nagy fitnesztermek figyelmét, hogy a jövőben mind jövedelmezőségük, mind pénzügyi stabilitásuk fejlesztése érdekében szükséges lépéseket tenniük.

\section{Köszönetnyilvánítás}

A publikáció elkészítését a “GINOP-2.3.2-15-2016-00062 Életminőség fejlesztése KeletMagyarországon: Táplálkozás-, teljesítménybiológiai és biotechnológiai experimentális kutatások és eszközfejlesztések a humán megbetegedések megelőzésére és kezelésére” projekt támogatta.

\section{Irodalomjegyzék}

[1] Afthinos Y., , Theodorakis N.D., Nassis P. (2005): Customers' expectations of service in Greek fitness centers: gender, age, type of sport center, and motivation differences. Managing Service Quality, Vol. 15 No. 3, pp. 245-258.

[2] Birher I., Pucsek J., Sándor L., Sztanó I. (2009): A vállalkozások tevékenységének gazdasági elemzése. Perfekt Zrt., Gyoma, 526 p.

[3] Bíró T., Pucsek J., Szántó I. (2010): Amit a mérleg mutat. SALDO, Budapest, 119 p.

[4] Breesch D., Vos S.,Scheerder J. (2015): The financial viability of the fitness industry in Belgium. Sport, Business and Management International Journal Vol. 5 No. 4, 2015pp. 365-385. 
[5] Chang K., Chelladurai P. (2003): System-based quality dimensions in fitness services: development of the scale of quality. The Service Industries Journal, Vol. 23 No. 5, pp. 65-83

[6] Frambach R.T, Schillewaert N. (2002): Organizational innovation adoption: a multi-level framework of determinants and opportunities for future research. Journal of Business Research, Vol. 55 No. 2, pp. 163-176.

[7] Gál J., Meszlényi R., Szabó Zs. (2005): Az éves beszámoló és a vállalati eredmény elemzése. Tomori Pál Főiskola, Kalocsa, 58 p.

[8] Gratton C., Taylor P. (2000): Economics of Sport and Recreation. Spon Press, London.

[9] Kim D., Kim S.Y. (1995): QUESC: an instrument for assessing the service quality of sport centers in Korea. Journal of Sport Management, Vol. 9 No. 2, pp. 208-220

[10] Lam E.T.C., Zhang J.J., Jensen, B.E. (2005): Service quality assessment scale (SQAS): an instrument for evaluating service quality of health-fitness clubs. Measurement in Physical Education and Exercise Science, Vol. 9 No. 2, pp. 79-111.

[11] Lucassen J.,van Schendel M. (2008): De fitnessbranche in beeld - 2008. Resultaten van de nationale fitnessmonitor (The fitness industry at a glance - 2008. Results of the national fitness monitor). W.J.H. Mulier/Arko Sports Media Instituut's, Hertogenbosch and Nieuwegein.

[12] Minton D., Stanley J. (2008): The health and fitness industry: trend and commercial realities. In Oakley B.,Rhys M. (Eds), The Sport and Fitness Sector: An Introduction. Routledge, New York, NY, pp. 23-55.

[13] Mullen S.P.,Whaley D.E. (2010): Age, gender, and fitness club membership: factors related to initial involvement and sustained participation. International Journal of Sport and Exercise Psychology Vol. 8 No. 1, pp. 24-35.

[14] Müller A., Bácsné Bába É., Gabnai Z., Pfau C., Pető K.(2019): A fitnesztrendek és új típusú mozgásformák társadalmi és gazdasági aspektusai. Acta Carulus Robertus 9(2) pp. 109.-122

[15] Polyakova O., Mirza M.T. (2016): Service quality models in the context of the fitness industry. Sport, Business and Management:International Journal Vol. 6 No. 3, 2016pp. 360-382

[16] Ryan R.M. , Frederick C.M. , Lepes D. , Rubio N., Sheldon, K.M. (1997): Intrinsic motivation and exercise adherence. International Journal of Sport Psychology, Vol. 28 No. 4, pp. 335-354.

[17] Scheerder J., Vos S. (2010): De fitnesssector in beeld. Basisrapportering over het Vlaamse Fitness Panel 2009 (VFPo9) (Fitness industry at a glance. Basic report of the Flemish fitness panel 2009) , K.U. Leuven/Research Unit of Social Kinesiology, Leuven

[18] Scheerder J., Vos, S. (2010): De fitnesssector in Vlaanderen en het Brussels Hoofdstedelijk Gewest. Een profielanalyse op basis van het Vlaamse Fitness Panel 2009 (VFPo9) (The fitness industry in Flanders and Brussels. A profile analysis based on the Flemish fitness panel 2009 (VFPo9)) (Praktijkgids Sportmanagement - V.3 Cases - Afl. 41/December 2010) , F \& G Partners, Antwerp, pp. 149-168.

[19] Tarnóczi T. előadása, 2017

[20] Woolf J. (2008): Competitive advantage in the health and fitness industry: developing service bundles. Sport Management Review , Vol. 11 No. 1, pp. 51-75.

[21] Yildiz S.M. (2011): An importance-performance analysis of fitness center service quality: empirical results from fitness centers in Turkey. African Journal of Business Management, Vol. 5 No. 16, pp. 7031-7041.

[22] Zeithaml V.A., Bitner, M.J. (2003): Services Marketing: Integrating Customer Focus Across the Firm. McGraw-Hill, New York, NY.

[23] 2000. évi C. tv. 